\title{
УДК 631.227:635.5.083
}

В.М. ПоляковСьКИй, канgияат ветеринарних наук, доцент,

В.М. МИХАЛЬСЬКА, канgиgат ветеринарних наук, gоцент,

Л.В. ШЕВЧЕНКО, gоктор ветеринарних наук, професор,

Національний університет біоресурсів і прироgокористування України, м. Київ

E-mail:pvam@ukr.net

\section{ВИМОГИ ДО ОБЛАШТУВАННЯ ПТАШНИКІВ ДЛЯ УТРИМАННЯ ЦЕСАРОК}

\begin{abstract}
Анотація. У даній статті розкриті вимоги до облаштування пташників і внутрішнього обладнання для утримання цесарок. При будівництві пташників необхідно враховувати поведінкові та фізіологічні особливості чесарок, від яких залежить їх ріст та розвиток, продуктивність, споживання корму та стійкість до хвороб. Для будівництва пташника вибирають піднесену ділянку або з невеликим ухилом, щоб талі і дощові води не накопичувалися і не застоювалися. Розмір

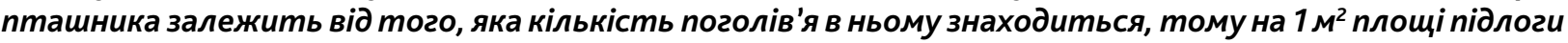
рекомендується розміщувати до 5-и голів. Дах пташника роблять односхилим. У приміщеннях для утримання цесарок використовують підстилку: торф, солому, тирсу, товщина підстилки 10-15 см. Протягом всього зимового періоду підстилку не прибирають, лише регулярно додають свіжу. Якщо підстилка сильно забруднена, то забруднену частину прибирають і додають чисту. Для зимового утримання цесарок приміщення добре утеплюють, не допускаючи в ньому вогкості та утворення цвілі. При літньому утриманні цесарок рекомендується обладнати для них вигульний дворик, обгороджений дротяною сіткою, навколо якого висаджують кущі й дерева або роблять навіси для захисту птиці від прямих сонячних променів. У зимовий час у пташнику встановлюють штучне джерело тепла. Сідала для цесарок виготовляють з обструганих брусків із закругленими верхніми краями, які встановлюють у протилежній стороні від вікон у горизонтальному вигляді. Гнізда встановлюють у пташнику задовго до того, як несучки стануть відкладати яйця, щоб цесарки встигли звикнути до них і відкладали яйця саме в гніздах. Годівниці роблять схожими на корития, що перешкоджає забрудненню і розкиданню корму. Поверх годівниці на кронштейнах кріплять вертушку, вона обертається навколо своєї осі й також перешкоджає розкиданню корму. Увисоту годівниці роблять такими, щоб краї бортиків виявилися на рівні спини птиці. Для напування цесарок краще використовувати вакуумні або ніпельні напувалки, які забезпечують їх свіжою проточною водою.
\end{abstract}

Ключові слова: цесарки, способи утримання, пташник, годівниці, гнізда

есарки часто викликають змішані емоції у людей: для одних вони чарівні та захопливі, для інших шумні й вимагають багато уваги. Не можна заперечувати, що їх відносно легко утримувати, якщо поряд достатньо вигульних майданчиків і немає сусідів. Це незалежні птахи, самодостатні збирачі, які ніколи не залишаться голодними. Якщо кури більш підходять для домашнього господарства, то цесарки більш дикі.

Наразі розведення цесарок в Україні не дуже поширене. Можливо, причина в тому, що цесарка походить 3 африканського континенту, де умови утримання мають певні особливості. Хоча цесарки добре пристосовуються до будь-яких кліматичних умов, легко переносять і спеку, і холод, стійкі до хвороб, невибагливі (Ebegbulem, 2018; Mafuvadze et al., 2008).

При вирощуванні цесарок необхідно знати їх поведінкові та фізіологічні аспекти. Цесарки - це стадні птахи, що необхідно враховувати при переміщенні птиці і при органі- зації випасу: чим більша кількість птиці в стаді, тим краще відбувається ріст і розвиток; мають генетичну схильність до польоту, тому необхідно продумати влаштування сіток або підрізати крила; неохоче несуться в штучних гніздах, надаючи перевагу кущам або траві; в осінньо-зимовий період для підвищення несучості необхідне додаткове освітлення; у віці старше 3-х років знижується репродуктивна функція; основним компонентом їх раціону $є$ зелена трава (Yildirim et al., 2020). Все це необхідно враховувати при будівництві приміщень для утримання птиці. У зв'язку з цим, метою роботи було охарактеризувати та узагальнити вимоги до облаштування пташників для утримання цесарок

Для будівництва пташника вибирають піднесену ділянку або з невеликим ухилом, щоб талі й дощові води не накопичувалися і не застоювалися. Стіни роблять з різноманітних матеріалів. Висота передніх дверей становить приблизно 2,2 м, задніх-1,7 м, ширина та довжина пташника залежать від кількості поголів'я у пташнику (рис. 1). На 


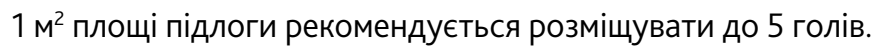
Дах пташника будують односхилим. У передній стінці роблять 1-2 вікна, які склять і зсередини обтягують дротяною сіткою.

Двері повинні відкриватися назовні і їх обов'язково потрібно обладнати порогом. Підлога може бути земляною або дерев'яною. На підлогу настеляють підстилку: торф, солому, тирсу, товщина підстилки - 10-15 см. Протягом всього зимового періоду підстилку не прибирають, лише регулярно додають свіжу. Якщо підстилка сильно забруднена, то забруднену частину прибирають і додають чисту. Встановлено, що цесарки комфортно себе почувають за досить низьких температур, але якщо в приміщенні тепло, то несучість підвищується. Для зимового утримання цесарок приміщення добре утеплюють, не допускаючи в ньому вогкості й утворення плісені. Також взимку в пташнику можна встановити штучне джерело тепла, наприклад, електричні брудери, електролампи з металевим абажуром-відбивачем, розташованим на висоті 15-20 см від підлоги.

При літньому утриманні цесарок рекомендується обладнати для них вигульний дворик, обгороджений дротяною сіткою (Koné et al., 1997). Висота огорожі складає не менше 1,5 м (рис. 2).

Солярій слід облаштувати з невеликим ухилом від основного приміщення. У якості покриття солярію можна використовувати крупний річковий пісок. Навколо вигульного двору висаджують кущі та дерева або роблять навіси для захисту птиці від прямих сонячних променів. Площа вигульного майданчика повинна відповідати площі пташника.

При утриманні великого поголів'я цесарок рекомендується приміщення розгородити на секції за допомогою сітки. Нижній край сітки слід прикріпити до дощок підлоги, щоб птиця не могла потрапляти в сусідні секції $(F A O, 2014)$.

Будова нижніх кінцівок цесарок дозволяє їм відпочивати, влаштувавшись на гілках дерев або жердинах. Під час присідання в дію вступає так званий механізм "замикання", у результаті чого прийняте сухожиллям і пальцями положення закріплюється. Тільки при зміні положення тіла змінюється й положення сухожилля. 3 цієї причини замість сідала не можна використовувати, наприклад, дошки, так як цесарки не зможуть на них закріплюватися.

Птиця прагне захопити вищі місця, постійно переміщаючись на сідалах. Тому сідала рекомендується виготовляти з обструганих брусків із закругленими верхніми краями. Ширина брусків становить 4 см, висота - 6-7 см. Сідала облаштовують у протилежній стороні від вікон у горизонтальному вигляді. Відстань від стіни до ближнього до неї сідала становить 40 см, висота від підлоги - 60 см. Сідала встановлюють на опорах. Конструкція опор повинна бути такою, щоб під час прибирання їх можна було підняти до стіни і зафіксувати. Під сідала на висоті 30-40 см поміщають піддони, на які буде потрапляти послід. На сідалах має вміщатися все поголів'я птиці. До сідала прикріплюють трапи, по яких птиця може піднятися на жердини. Сідала облаштовують на висоті 40-50 см від підлоги з розрахунку

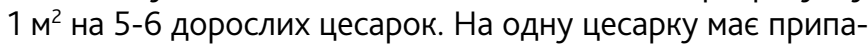
дати 15-20 см сідала. Сідало виготовляють з планок перерізом 4×5 см дещо закругленої форми. Відстань від стіни

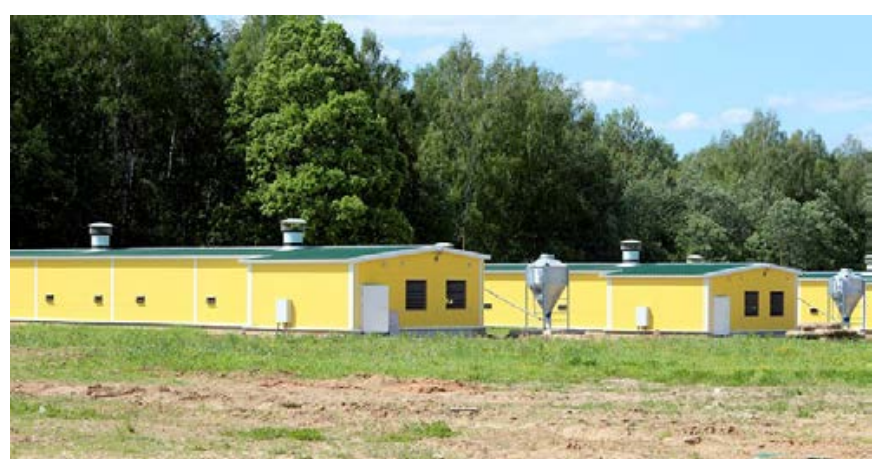

Рис.1. Пташники для утримання цесарок

до крайнього сідала становить 25-30 см, між рейками - 3540 см. При використанні чистої глибокої підстилки встановлювати сідала не обов'язково (рис. 3).

Гнізда встановлюють у пташнику, щоб птиця відкладала яйця у встановлених місцях і вони не бруднилися. Конструкція гнізда повинна бути легкою, щоб цесарки вільно потрапляли в нього, а також для зручного чищення гнізда та збору яєць. Гнізда встановлюють у пташнику задовго до того, як несучки почнуть відкладати яйця, щоб цесарки встигли звикнути до них і неслись саме у гніздах. Гнізда слід ставити у затемненому місці пташника, тому що в період яйцекладки несучки потребують усамітнення. Матеріалом для гнізд можуть служити фанера або тес. Гнізда найкраще розташовувати у вигляді етажерки у 2-3 яруси. Нижній ярус повинен знаходитися на висоті 20-40 см від підлоги. Біля входу встановлюють поріг висотою 5 см , перед гніздом - поличку для зльоту.

Дах нижнього ярусу одночасно $є$ й підлогою для верхнього ярусу, їі роблять з нахилом 45․ Це потрібно для того, щоб птиця не засиджувалась і не засмічувала підлогу послідом. Гніздо вистилають чистою та сухою підстилкою - сіном, соломою або дерев'яною стружкою. Під гнізда можна використовувати прості кошики або дерев'яні чи пластмасові ящики. Цесарка сидить у гнізді до 1,5 год., тому одне гніздо можуть використовувати 5-6 несучок.

Розмір гнізда становить 40×30×30 см. Гнізда розміщують уздовж стін. Особливістю поведінки цесарок $\epsilon$ те, що вони погано використовують штучні гнізда. Для відкладання яєць вони відшукують затишні місця на вигулі або роблять це просто на підлозі приміщення. При утриманні великого стада всі цесарки відкладають яйця в одному груповому гнізді.

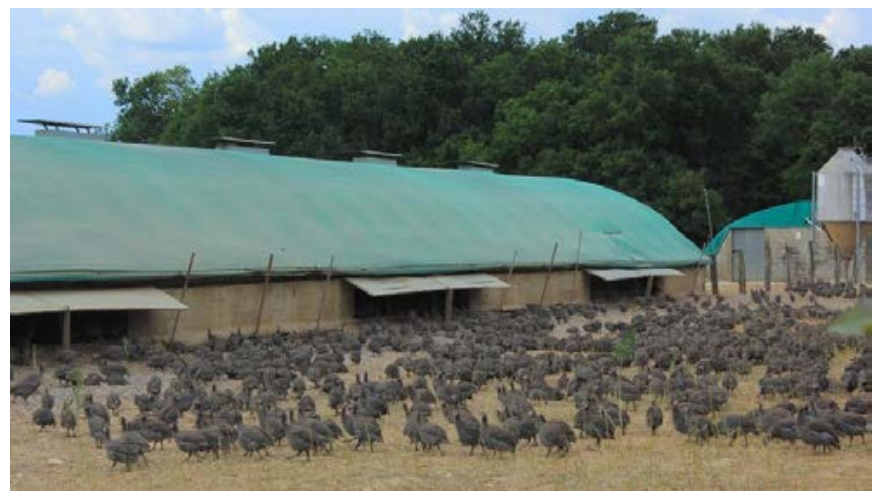

Рис.2. Утримання дорослого поголів'я цесарок 


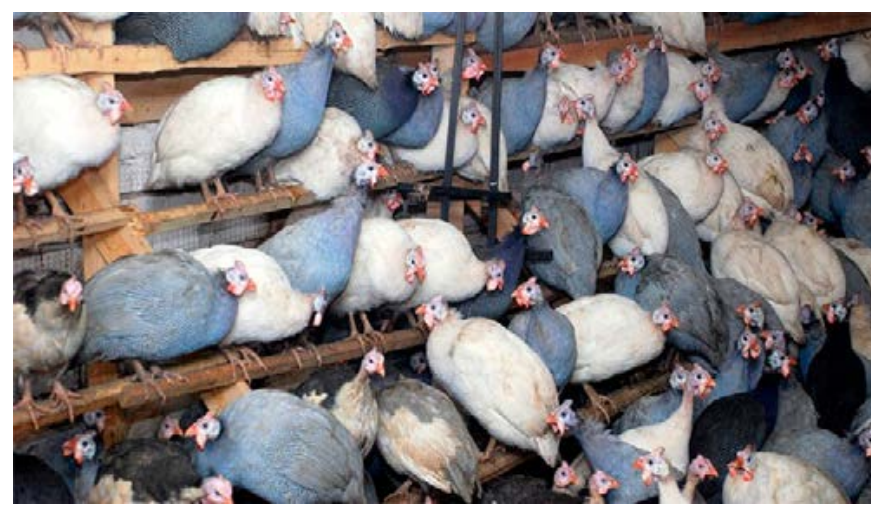

Рис.3. Облаштування сідал для цесарок

Годівниці та напувалки слід розташувати впритул до стіни, щоб середина приміщення була вільна для шлюбних ігор. Фронт годівлі на одну птицю становить 5-6 см, напування - 1,5-2 см. Годівниці обов'язково повинні мати бортики, які перешкоджають розкиданню корму. Над годівницями слід натягнути дріт або встановити обертову планку, тоді птиця не зможе проникати в годівниці і забруднювати корм. На вигульному дворі також рекомендується ставити годівниці та напувалки (рис. 4).

Годівниці можуть бути різними, їх конструкції залежать від типу годівлі (для сухих кормових сумішей або для вологих мішанок). Годівниці для вологих мішанок рекомендується виготовляти з оцинкованого заліза або тесу, тоді їх легше буде мити та дезінфікувати. Годівниці роблять схожими на коритця. Уздовж боків з внутрішньої сторони встановлюють бортики, що перешкоджають забрудненню і розкиданню корму. Поверх годівниці на кронштейнах кріплять вертушку, вона обертається навколо своєї осі й також перешкоджає розкиданню корму. У висоту годівниці роблять такими, щоб краї бортиків виявилися на рівні спини птиці. Така висота забезпечує мінімальне розсипання корму (Yıldırım, 2007).

Годівницю слід заповнювати на 1/4 або 1/3. Якщо їі заповнити наполовину, то втрата корму збільшиться на 2-3\%, при заповненні на 3/4 - на 6-7\%. При максимальному заповненні годівниці можна втратити до 20\% корму. Розмір годівниці має бути таким, щоб до неї одночасно могла підійти вся птиця. Так, для 20 голів виготовляють двосторонню годівницю довжиною 1-1,5 м, шириною 24 см, з бортиками висотою $13 \mathrm{~cm}$.

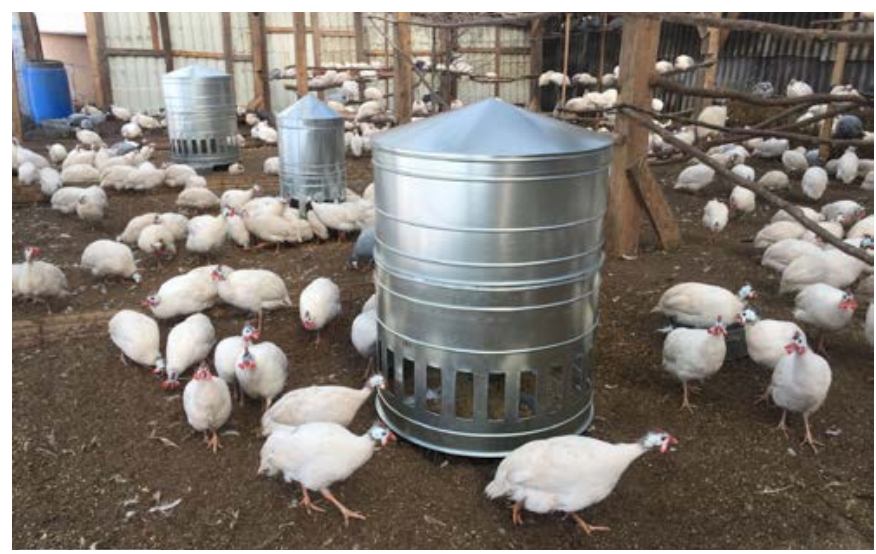

Рис.5. Годівниці для цесарок

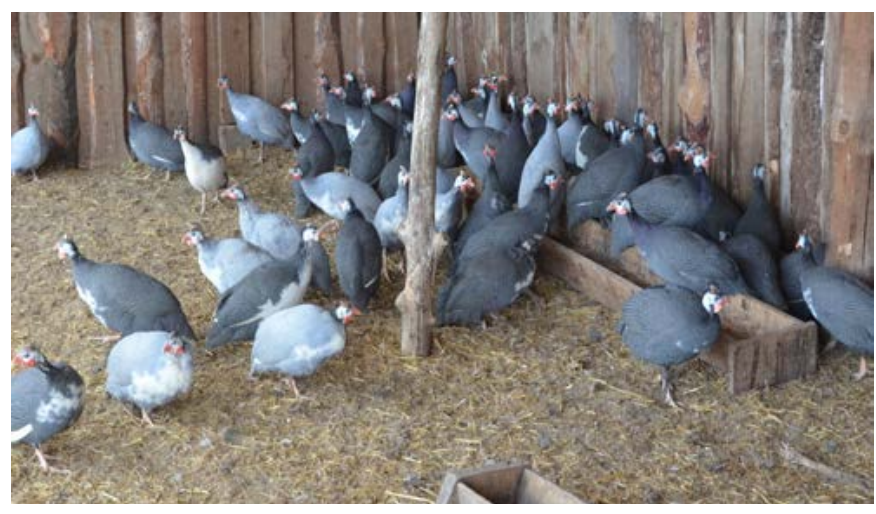

Рис.4. Годівниця на вигульному майданчику

Для сухих кормів часто використовують автоматичні годівниці, в які вміщається не менше добової норми корму (рис. 5). Форма бункера годівниці циліндрична або конусоподібна, нижні краї бункера не стикаються з дном. У міру споживання корму, в годівницю надходить нова порція (Сахацький та ін., 2020).

В умовах присадибної ділянки в якості напувалок використовують тази або неглибокі ємності, які встановлюють на підставки. Найкраще використовувати вакуумні та ніпельні напувалки (рис. 6). При такому напуванні птиця завжди буде забезпечена свіжою проточною водою.

Зольні ванни встановлюють для чищення оперення, шкірного покриву та для позбавлення від шкірних паразитів. Для цього підійдуть ящики або листи висотою 15 20 см, їх довжина залежить від кількості поголів'я. Коритця заповнюють сухим піском і деревним попелом у рівних пропорціях. Замість піску влітку можна використовувати дорожній пил. Зольні ванни ставлять на вигульних дворах.

На стан птиці та її продуктивність впливає зовнішнє середовище, з яким вона знаходиться в постійній взаємодії. Якщо відхилення від встановлених норм значні, то це призводить до порушення нормальних фізіологічних процесів, перевитрати кормів, зменшення продуктивності, погіршення здоров'я птиці (Nwagu, 1997).

Зниження температури повітря у приміщенні призводить до того, що корм витрачається не на отримання продукції, а на обігрів організму птиці. Якщо птиця розпускає крила, збільшуючи захисний шар повітря, скупчується, то швидше за все, температура у пташнику занадто низька. Підвищена температура повітря стає

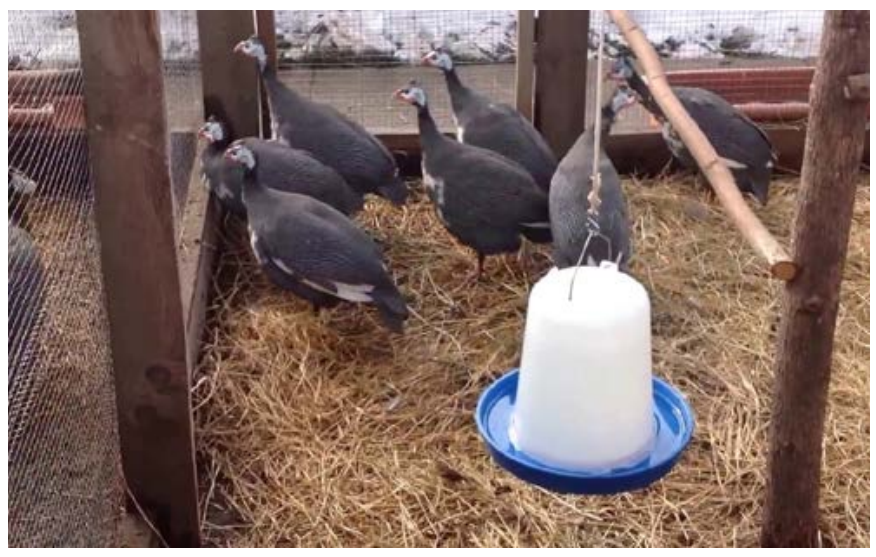

Рис.6. Напувалки для цесарок 
причиною поганого споживання кормів, внаслідлк чого відбувається порушення обміну речовин. Ознаками надмірно високої температури в пташнику є часте дихання птиці з відкритим дзьобом, підвищена спрага. За нормальної температури повітря цесарки добре поїдають корм, рухливі, розосереджені по всьому приміщенню. Так, оптимальною температурою у приміщенні при утриманні цесарок у холодний період року $\epsilon 16^{\circ} \mathrm{C}$.

Вологість, як і температура повітря, позначається на тепловіддачі організму птиці. Якщо у пташнику відносна вологість опускається нижче 50\%, то це часто викликає подразнення дихальних шляхів, слизових оболонок очей, підвищення ламкості пера. Оптимальною відносною вологістю $є$ 65-70\%.

Хімічний склад повітря також впливає на організм цесарок. Внаслідок розкладання сечі та калу в приміщенні накопичується аміак, також це відбувається при невчасному прибиранні забрудненої й вологої підстилки. Внаслідок гниття білкових речовин у повітрі підвищується рівень сірководню. Якщо у приміщенні накопичилось багато шкідливих газів, то це пригнічує птицю, у результаті знижується її продуктивність, уражається центральна нервова система, що призводить до паралічу дихальних шляхів і до ії загибелі. 3 цієї причини важливо у пташнику обладнати вентиляцію, а також періодично перевіряти справність вентиляційного обладнання. Щоб не допустити забруднення повітря у пташнику, слід утримувати його в чистоті та періодично провітрювати (Camas-Robles et al., 2020).

\section{В.М. Поляковский,}

\section{В.М. Михальская, Л.в. Шевченко}

\section{Требования к устройству птичников для содержания цесарок}
Аннотация. В данной статье раскрыты требования к устройству птичников и внутреннего оборудования для содержания цесарок. При строительстве птичников необходимо учитывать поведенческие и физиологические особенности цесарок от которых зависит их рост и развитие, производительность, потребление корма и устойчивость к болезням. Для строительства птичника выбирают возвышенный участок или с небольшим уклоном, чтобы талые и дождевые воды не накапливались и не застаивались. Размер птичника зависит от того, какое количество

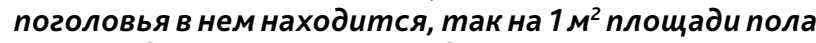 рекомендуется размещать до 5-и голов. Крышу птичника делают наклонной. В помещениях для содержания цесарок используют подстилку: торф, солому, опилки, толщина подстилки -
10-15 см. В течение всего зимнего периода подстилку не убирают, только регулярно добавляют свежую. Если подстилка сильно загрязнена, то загрязненную часть убирают и добавляют чистую. Для зимнего содержания цесарок помещение хорошо утепляют, не допуская в нем сырости и образования плесени. При летнем содержании цесарок рекомендуется оборудовать для них выгульный дворик, огороженный проволочной сеткой, вокруг которого высаживают кусты и деревья или делают

Світло здійснює позитивний вплив на продуктивність птиці, а також на ріст і розвиток молодняку. Потоки світла потрапляють на сітківку ока і у вигляді нервових імпульсів стимулюють фізіологічні процеси в організмі. Це сприяє підвищенню несучості, відтворювальних якостей, у молодняку підвищується приріст живої маси, тонус організму підтримується в нормі.

Інтенсивний шум несприятливо позначається на стані птиці, збуджуючи їі нервову систему. Сильні звуки стають причиною лякливості, розполохують птицю. Ритм дихання змінюється, температура тіла знижується, робота нервової системи порушується. Якщо шум діє на цесарок протягом тривалого часу, то їх ріст може сповільнитися, продуктивність знизитися, жива маса також зменшується. Тому неприпустимо проводити у присутності птиці роботи у пташнику, що викликають сильний шум, також у пташнику не рекомендується голосно розмовляти, а тим більше кричати.

\section{ВИСНОВКИ}

Таким чином, розглянувши вимоги до облаштування пташників для цесарок, можна уникнути багатьох помилок при їх вирощуванні. Висока адаптація цесарок до умов навколишнього середовища, невибагливість до кормів, стійкість до хвороб може бути підставою для їх вирощування у господарствах України.

Перспективи подальших досліджень полягають у вивченні якості продукції, одержаної від цесарок за різних способів утримання.

навесы для защиты птицы от прямых солнечных лучей. В зимнее время в птичнике устанавливают искусственный источник тепла. Насесты для цесарок изготавливают из остроганных брусков с закругленными верхними краями, которые устанавливают в противоположной стороне от окон в горизонтальном виде. Гнезда устанавливают в птичнике задолго до того, как несушки станут откладывать яйца, чтобы цесарки успели привыкнуть кним и откладывали яйца именно в гнездах. Кормушки делают похожими на корытиа, что препятствует загрязнению и разбрасыванию корма. Вверху кормушки на кронштейнах крепят вертушку, она вращается вокруг своей оси и также препятствует разбрасыванию корма. Высота кормушки должна быть такой, чтобы края бортиков оказались на уровне спины птицы. Для поения цесарок лучше использовать вакуумные или ниппельные поилки, которые обеспечивают их свежей проточной водой.

Ключевые слова: цесарки, способы содержания, птичник, кормушки, гнезда

V.M. POLIAKOVSKYI, Candidate of Veterinary Sciences, Associate Professor,

V.M. MYKHALSKA, Candidate of Veterinary Sciences, Associate Professor,

L.V. SHEVCHENKO, Doctor of Veterinary Sciences,

Professor,

National University of Life and Environmental Science

Ukraine, Kyiv,

E-mail: pvam@ukr.net 


\section{Requirements for the arrangement of poultry houses for keeping guinea fowl}

\author{
Abstract. This article discloses the requirements for the \\ installation of poultry houses and indoor equipment for \\ keeping guinea fowl. In the construction of poultry houses \\ it is necessary to take into account the behavioral and \\ physiological characteristics of guinea fowl on which their \\ growth and development, productivity, feed consumption \\ and disease resistance. For construction of a poultry house \\ choose the elevated site or with a small slope that thaws and \\ rain waters did not collect and did not stagnate. The size of \\ the poultry house depends on the number of livestock in \\ it, so it is recommended to place up to 5 heads per $1 \mathrm{~m}^{2}$ of \\ floor area. The roof of the poultry house is made sloping. \\ Litter is used in the premises for keeping guinea fowl: peat, \\ straw, sawdust, litter thickness $-10-15 \mathrm{~cm}$. During the whole \\ winter period the litter is not removed, only fresh is added \\ regularly. If the litter is heavily soiled, the contaminated part \\ is removed and a clean one is added. For winter keeping of \\ guinea fowl the room is well warmed, without allowing in it \\ humidity and formation of a mold.
}

\begin{abstract}
When keeping guinea fowl in the summer, it is recommended to equip them with a walking yard, fenced with wire mesh, around which bushes and trees are planted or canopies are made to protect the bird from direct sunlight. In winter, an artificial heat source is installed in the poultry house, for example, electric brooders, electric lamps with a metal shade-reflector located at a height of $15-20 \mathrm{~cm}$ from the floor. Seats for guinea fowl are made of chipped bars with rounded upper edges, which are installed on the opposite side of the windows in a horizontal form. Nests are set in the henhouse long before the laying hens begin to lay eggs, so that the guinea fowl have time to get used to them and lay eggs in the nests. Feeders are made like troughs, which prevents contamination and scattering of food. A turntable is mounted on the brackets on top of the feeder, it rotates around its axis and also prevents the feed from scattering. At the height of the feeder is made so that the edges of the sides were at the level of the back of the bird. It is better to use vacuum or nipple drinkers to water the guinea fowl, which provide them with fresh running water.
\end{abstract}

Key words: guinea fowl, methods of keeping, poultry house, feeders, nests

\section{Література}

Сахацький М.І., Ібатуллін І.І., Поляковський В.М., Михальська В.М., Кривенок М.Я., Чепіль Л.В. Утримання і гігієна тварин. Утримання птиці. Ч.1. [Навчальний посібник]. К.: Вид-во ФОП "Ямчинський О.", 2020. 330 с.

Camas-Robles G., Ruiz-Sesma B., Mendoza-Nazar P., Portillo-Salgado R., Hernández-Marín A., Cigarroa-Vázquez F. Comportamiento productivo y composición de la canal de la gallina de Guinea (Numida meleagris). Abanico Veterinario. 2020. Vol.10. P. 1-14. doi: 10.21929/abavet2020.34.

Ebegbulem V.N. Prospects and challenges to guinea fowl (Numida meleagris) production in Nigeria. International Journal of Avian E Wildlife Biology. 2018. Vol. 3(3). P. 182-184. https://doi.org/10.15406/ijawb.2018.03.00083.

FAO. Decision tools for family poultry development. FAO Animal Production and Health Guidelines. 2014. N. 16. Rome, Italy. URL: http://www.fao. org/3/a-i3542e.pdf [in English].

Koné G.A, Kouassi G.F, Kouakou N.D.V, Kouba M. Diagnostic of guinea fowl (Numida meleagris) farming in Ivory Coast. Poultry Science. 2018. Vol. 97(12). P. 4272-4278. https://doi.org/10.3382/ps/pey290/

Mafuvadze B., Nyanungo M., Saina H., Gorejena B., Mashayamombe N., Erlwanger K.H. Deprivation of Drinking Water for up to 48 Hours Does Not Affect the Osmotic Fragility of Erythrocytes from Captive Helmeted Guinea Fowl (Numida meleagris). International Journal of Poultry Science. 2008. Vol. 7(1). P. 1006-1009. doi: 10.3923/ijps.2008.59.63.

Nwagu B.I. Factors affecting fertility and hatchability of guinea fowl eggs in Nigeria. World's Poultry Science Journal. 1997. Vol. 53(3). P. 279-286. doi: 10.1079/WPS19970022.

Yıldırım A. Nutrition of Guinea Fowl Breeders. Conference: The 8th Asian Pacific Poultry Conference, Science to Solutions. Bangkok, Thailand. 2007. URL: https://www.researchgate.net/publication/203330598.

Yildirim A., Eleroglu H., Buman M. Meat physico-chemical composition of guinea fowl fed organic diets supplemented with dry oregano leaf. Large Animal Review. 2020. Vol. 26(4). P. 173-180.

\section{References}

Camas-Robles, G., Ruiz-Sesma, B., Mendoza-Nazar, P., Portillo-Salgado, R., Hernández-Marín, A., Cigarroa-Vázquez, F. (2020). Comportamiento productivo y composición de la canal de la gallina de Guinea (Numida meleagris). Abanico Veterinario. 10. 1-14. doi: 10.21929/abavet2020.34 (in Spanish). Ebegbulem, V.N. (2018). Prospects and challenges to guinea fowl (Numida meleagris) production in Nigeria. International Journal of Avian E Wildlife Biology. 3 (3). 182-184. https://doi.org/10.15406/ijawb.2018.03.00083 [in English].

FAO. (2014). Decision tools for family poultry development. FAO Animal Production and Health Guidelines No. 16. Rome, Italy. URL: http://www.fao. org/3/a-i3542e.pdf

Koné, G.A, Kouassi, G.F, Kouakou, N.D.V, Kouba, M. (2018). Diagnostic of guinea fowl (Numida meleagris) farming in Ivory Coast. Poultry Science. 97.12. 4272-4278. https://doi.org/10.3382/ps/pey290/ [in English].

Mafuvadze, B., Nyanungo, M., Saina, H., Gorejena, B., Mashayamombe, N., Erlwanger, K.H. (2008). Deprivation of Drinking Water for up to 48 Hours Does Not Affect the Osmotic Fragility of Erythrocytes from Captive Helmeted Guinea Fowl (Numida meleagris). International Journal of Poultry Science, 7(1), 1006-1009. doi: 10.3923/ijps.2008.59.63 [in English].

Nwagu, B.I. (1997). Factors affecting fertility and hatchability of guinea fowl eggs in Nigeria. World's Poultry Science Journal, 53(3), 279-286. doi: 10.1079/ WPS19970022. [in English].

Sakhatskyi, M.I., Ibatullin, I.I., Poliakovskyi, V.M., Mykhalska, V.M., Kryvenok, M.Ya., Chepil, L.V. (2020). Utrymannia i hihiiena tvaryn. Utrymannia ptytsi. Ch.1. Navchalnyi posibnyk. [Keeping and hygiene of animals. Poultry keeping. Part 1 Tutorial] K.: Vyd-vo FOP "lamchynskyi O.", 330. [in Ukrainian]. Yildirim, A. (2007). Nutrition of Guinea Fowl Breeders. Conference: The 8th Asian Pacific Poultry Conference, Science to Solutions. Bangkok, Thailand. 2007, URL: https://www.researchgate.net/publication/203330598 [in English].

Yildirim, A., Eleroglu, H., Buman, M. (2020). Meat physico-chemical composition of guinea fowl fed organic diets supplemented with dry oregano leaf. Large Animal Review, 26(4), 173-180. [in English]. 